\title{
Entomofauna of hazel (Corylus avellana L.) under additional protection with bio-products
}

\author{
Entomofauna leszczyny (Corylus avellana L.) \\ przy dodatkowej ochronie biopreparatami
}

\author{
Emilia Ludwiczak $^{1 *}$, Mariusz Nietupski ${ }^{1}$, Bogumił Markuszewski $^{2}$, Agnieszka Kosewska $^{1}$
}

\section{Summary}

Conventional crop cultivation based on chemical plant protection products and synthetic fertilizers creates an apparent image of effective protection. Irrational usage of chemical products in horticulture production, with an aim at increasing yields results in a decrease of fruit quality and leads to degradation of the environment. Mandatory application of the principles of integrated plant protection, which became effective on 1st January 2014, has forced the combined usage of chemical, biological and physical methods. The aim of our study was to assess the effect of an application of additional plant protection with bi-products such as EmFarma, Polyversum WP on the occurrence of entomofauna on hazel plants (Corylus avellana L.). The study has demonstrated that aphids, with the dominant species Myzocallis coryli Goe. were a potentially dangerous pest of hazel plantations. It was also determined that the product Polyversum WP stimulates more abundant occurrence of Carabidae and phytophagous species inhabiting hazel leaves. Moreover, due to less numerous presence of phytophages, hazel aphid in particular, it is recommended to perform an additional plant protective treatment with the probiotics EmFarma Plus and EmFarma 5.

Key words: hazel; biopreparations; Polyversum WP; Effective Microorganisms (EM); Carabidae

\section{Streszczenie}

Uprawa roślin w systemie konwencjonalnym oparta na chemicznych środkach ochrony roślin i syntetycznych nawozach stwarza wyłącznie pozorne wrażenie skutecznej ochrony. Nieracjonalna chemizacja sadownictwa mająca na celu maksymalizację plonu powoduje spadek jakości owoców oraz prowadzi do degradacji środowiska. Obowiązek stosowania zasad integrowanej ochrony roślin wprowadzony 1 stycznia 2014 roku wymusił łączenie metod chemicznych, biologicznych i fizycznych. Celem badań była ocena wpływu stosowania dodatkowej ochrony biopreparatami (EmFarma, Polyversum WP) na występowanie entomofauny leszczyny. Badania wykazały, że potencjalnie groźnymi szkodnikami uprawy były mszyce z dominującym gatunkiem Myzocallis coryli Goe. Stwierdzono, że działanie preparatu Polyversum WP stymuluje występowanie naziemnych Carabidae i gatunków roślinożernych zasiedlających liście leszczyny. Ponadto, ze względu na mniej liczny pojaw fitofagów, w szczególności zdobniczki leszczynowej, zaleca się w uprawach tej rośliny stosowanie dodatkowej ochrony probiotykami: EmFarma Plus i EmFarma 5.

Słowa kluczowe: leszczyna; biopreparaty; Polyversum WP; Efektywne Mikroorganizmy (EM); Carabidae

\footnotetext{
Uniwersytet Warmińsko-Mazurski w Olsztynie

${ }^{1}$ Katedra Entomologii, Fitopatologii i Diagnostyki Molekularnej

Prawocheńskiego 17, 10-720 Olsztyn

${ }^{2}$ Katedra Ogrodnictwa

Prawocheńskiego 21, 10-720 Olsztyn

*corresponding author: emilia.ludwiczak@uwm.edu.pl
} 


\section{Wstęp / Introduction}

Światowa produkcja orzechów laskowych ze względu na zwiększający się popyt, sukcesywnie rośnie i zaliczana jest do jednych $\mathrm{z}$ najbardziej perspektywicznie rozwijających się upraw sadowniczych (Gantner 2010). Owoce leszczyny pospolitej (Corylus avellana L.) produkowane w Polsce, ze względu na panujące warunki, charakteryzują się wyższymi wartościami odżywczymi i biologicznymi w porównaniu z produktami wiodących liderów (Turcja, Włochy, Hiszpania, Stany Zjednoczone) (Piskornik i wsp. 1998; Ghirardello i wsp. 2010; Zdyb 2010; Ciemniewska i Ratusz 2012). Jednocześnie, panujące czynniki klimatyczne determinują zmienną plonotwórczość tych krzewów, co powoduje spadek opłacalności ich produkcji (Markuszewski i wsp. 2017). Największe straty gospodarcze (do $50 \%$ powoduje jednak szkodliwa entomofauna, której zapobieganie występowania jest dodatkowo utrudnione ze względu na duże zróżnicowanie fitofagów (Sądej i wsp. 1997; Gantner 2009). Leszczyna w Polsce należy do upraw o charakterze małoobszarowym, dla których obserwuje się sukcesywny spadek liczby dozwolonych i zarejestrowanych środków ochrony roślin. Skutkuje to wzrostem szkód wyrządzanych przez agrofagi (Gantner 2010). Zgodnie z Zaleceniami Ochrony Roślin (2016/17) do ich zwalczania dopuszczone do obrotu są 3 insektycydy: Miros 20 SP, Mospilan 20 SP i Stonkat 20 SP (www.ior.poznan.pl/baza/). Coraz większy nacisk kładzie się na przejście z konwencjonalnego rolnictwa, stosującego duże ilości syntetycznych środków ochrony roślin, na rolnictwo zrównoważone wykorzystujące preparaty pochodzenia naturalnego i bezpieczne dla środowiska (Twardowski 2013; Kosicka i wsp. 2015). W związku z tym zasadnym wydaje się być zbadanie wpływu alternatywnych preparatów do zwalczania najgroźniejszych chorób i szkodników w uprawie tego gatunku, ocena ich skuteczności oraz stosowanie nowych technik ochrony.

Do preparatów nietestowanych dotąd w ochronie leszczyny należą probiotyki (EmFarma) i Polyversum WP, które mogą przyczynić się do zmniejszenia liczebności szkodliwej entomofauny, przy jednoczesnym ograniczaniu stosowania środków chemicznych w sadownictwie oraz wspieraniu bioróżnorodności (Małuszyńska i wsp. 2012; Kosakowski i wsp. 2013; Nikolova i Georgieva 2015; Paśmionka i Kotarba 2015). Technologia stosowania Efektywnych Mikroorganizmów (EM) opracowana w drugiej połowie XX wieku, opiera się na działaniu niespełna 80 gatunków pożytecznych mikroorganizmów wyizolowanych $\mathrm{z}$ ich naturalnego środowiska (m.in. bakterie mlekowe, bakterie fotosyntetyzujące, drożdże, promieniowce czy pleśnie). Preparaty EM zawierają konsorcjum mikroorganizmów wzajemnie egzystujących i oddziałujących korzystnie na organizmy wyższe, a ich działanie oparte jest wyłącznie na naturalnych procesach (Daly i Stewart 1999; Paśmionka i Kotarba 2015; Morelowska i wsp. 2017). Zydlik (2008) podkreśla, iż wielokrotne badania wykazały ich pozytywny wpływ na rośliny sadownicze. Preparaty EM uczestniczą ponadto w rozkładzie substancji toksycznych zawartych $\mathrm{w}$ glebie, przyśpieszają wzrost roślin, zapobiegają występowaniu zróżnicowanych chorób oraz odstraszają szkodniki poprzez wydzielanie substancji o działaniu toksycznym (Wolna-Maruwka i wsp. 2010).

W sadach leszczynowych pod względem struktury stosowanych środków ochrony roślin dominują fungicydy $95,8 \%$, insektycydy stanowią 3,6\%, a akarycydy $0,6 \%$ (Gantner 2009). Do biologicznych fungicydów dopuszczonych do obrotu w systemie rolnictwa integrowanego zaliczamy Polyversum WP. Jest to środek cechujący się wysoką skutecznością oraz pełnym bezpieczeństwem dla środowiska. Preparat ten w swoim działaniu wykorzystuje naturalne procesy samoregulacyjne grzyba Pythium oligandrum Drechsler zasiedlającego ryzosferę, który eliminuje poprzez konkurencję inne grzyby chorobotwórcze. Ponadto, biofungicyd ten działa stymulująco na wzrost i rozwój całej rośliny poprzez wydzielanie do jej wnętrza fitohormonów, cukrów i fosforu bioracych czynny udział w procesach wzrostowych rośliny i wzmacnianiu jej odporności (Jamiołkowska i Hetman 2016).

Celem prowadzonych badań była ocena stanu entomofauny pożytecznej i szkodliwej upraw leszczyny przy dodatkowej ochronie biopreparatami (probiotyki, Polyversum WP).

\section{Materiały i metody / Materials and methods}

\section{Teren i miejsce badań}

Badania dotyczące entomofauny zasiedlającej sad leszczynowy prowadzono w Tuszewie koło Lubawy w województwie warmińsko-mazurskim (UTM DE 12) w latach 2014-2015. Materiałem badań były 8-letnie, niskopienne nasadzenia leszczyny o powierzchni 1,5 ha, rosnące na glebach piaszczystych zaklasyfikowanych do V klasy bonitacyjnej. Sad leszczynowy usytuowany był około $200 \mathrm{~m}$ od drogi wojewódzkiej nr 541 i 175 m od zabudowań. Od południowego zachodu plantacja graniczyła z 5,5 ha sadem wiśniowym (A), natomiast od północnego zachodu z zadrzewieniem śródpolnym (B). Pozostałe użytki sąsiadujące z leszczyną były gruntami rolnymi (C, D) (w 2014 roku uprawiano jęczmień jary i ziemniaki, w 2015 roku mieszankę jarą i żyto ozime) (rys. 1).

W badanym sadzie wyznaczono 3 strefy w układzie pasowym. Każda z nich składała się z 60 drzew odmiany Kataloński, oddalonych od siebie o 20 m (rys. 1). Pierwszą strefę (1) stanowiła kontrola, w której stosowano wyłącznie standardowe środki chemiczne aplikowane na powierzchni całego sadu leszczynowego zgodnie z programem ochrony roślin sadowniczych na lata 2014-2015. $\mathrm{W}$ pozostałych strefach zastosowano dodatkowe kombina- 
cje ochrony: Polyversum WP w drugiej strefie (2) i probiotyki (EM) w trzeciej strefie badań (3).

Podczas dwuletnich obserwacji w każdej kombinacji doświadczenia wykonano 4-krotnie opryskiwanie preparatami z substancją czynną mankozeb i tiuram przeciwko moniliozie leszczyny. Wykorzystywane preparaty stosowano z uwzględnieniem faz rozwojowych leszczyny. W stanie bezlistnym drzew, wiosną i jesienią wykonano także opryskiwanie preparatem miedziowym $(2,4 \mathrm{~kg} / \mathrm{ha})$, a w 2015 roku ze względu na wysokie plony orzechów dodatkowo zastosowano preparat Alkalin KP (5 1/1,5 ha). Ochrona leszczyny przeciwko szkodnikom polegała na zastosowaniu insektycydów Treol 770 EC i Mospilan 20 SP, a nawożenie gleby wykonano według zaleceń nawozowych. Dodatkowo w okresie wegetacji dokarmiano 9-krotnie drzewa dolistnie (mocznik, siarczan magnezu, $\mathrm{Zn}, \mathrm{B}, \mathrm{Mg}, \mathrm{K}$, $\mathrm{Si}, \mathrm{Cu}$, Tytanit i inne mikroelementy). Ponadto, na terenie plantacji pielęgnacja gleby polegała na 2-krotnym koszeniu zachwaszczenia i 3-krotnym spulchnianiu glebogryzarką do głębokości $5 \mathrm{~cm}$.

Dodatkowo w drugiej kombinacji (2) wykonano 5-krotnie opryskiwanie preparatem Polyversum WP, a w trzeciej (3) drzewa opryskiwano 4-krotnie mieszaniną preparatów EmFarma Plus i EmFarma 5. Polyversum WP stosowano w dawce $20 \mathrm{~g} / 1501$ wody w fazie kwitnienia, po okresie kwitnienia, podczas wzrostu owoców i dwukrotnie przed ich zbiorem. Natomiast dawki probiotyków były zróżnicowane: po okresie kwitnienia EmFarma Plus (10 1/ha) + EmFarma $5(0,2 \%)$, podczas wzrostu owoców EmFarma Plus $(20$ l/ha) + EmFarma $5(0,2 \%)$ i przed zbiorem owoców 2-krotnie EmFarma Plus (20 1/ha) + EmFarma 5 (0,2\%).

\section{Obserwacje entomologiczne}

Entomofaunę zasiedlającą liście leszczyny pozyskiwano za pomocą czerpaka entomologicznego, stosując 25 -krotne otrząsanie gałązek z losowo wybranych krzewów w każdym rzędzie. W 2014 roku ocenę entomofauny liści leszczyny przeprowadzono 3-krotnie (lipiec-wrzesień), natomiast w 2015 roku - 7-krotnie (maj-wrzesień). Strukturę dominacji odłowionych zoofagów z podziałem na klasy dominacji przedstawiono według Kasprzaka i Niedbały (1981). Przyjęty układ dominacji wyróżnia 5 klas: eudominanty $(>10 \%$ osobników zgrupowania), dominanty (10-5,1\%), subdominanty $(5-2,1 \%)$, recedenci $(2-1,1 \%)$ i subrecedenci $(<1 \%)$.

Entomofaunę epigeiczną odławiano za pomocą zmodyfikowanych pułapek Barbera, wypełnionych w $1 / 3$ roztworem $4 \%$ formaliny (Kotze i wsp. 2011). Na każdej powierzchni badawczej zainstalowano 5 pułapek oddalonych od siebie o 10 metrów. Pułapki Barbera eksponowane były od 1 maja do 15 października 2014 roku (168 dni), a owady wybierano co 2 tygodnie. Zebrany materiał oznaczono za pomocą klucza Hůrki (1996), stosując nomenklaturę za Stachowiakiem (2008). Zebrany materiał opracowano pod względem ekologicznym korzystając z prac Larssona (1939), Aleksandrowicza (2004) oraz Kosewskiej i wsp. (2016).

\section{Opracowanie statystyczne}

Przy opracowaniu wyników posłużono się wskaźnikami: ogólnej różnorodności gatunkowej Shannona-Wienera (H') oraz równomierności udziału gatunków Pielou (J'). Dane prezentujące liczebność odłowionych gatunków i osobników Carabidae w badanych kombinacjach charakteryzowały się rozkładem unimodalnym (test W Shapiro-Wilka). Do oceny różnic między średnimi zastosowano więc model GLM (Generalized Linear Model) uwzględniający typ rozkładu danych Poisson'a. Oceny podobieństwa zgrupowań Carabidae w badanych kombinacjach dokonano przy użyciu niemetrycznego skalowania wielowymiarowego NMDS, przy zastosowaniu miary podobieństwa Braya-Curtisa. Metoda ta pozwala na ocenę zgrupowań Carabidae na podstawie podobieństwa między poszczególnymi próbami, analizując dane dotyczące liczby odłowionych gatunków i osobników. Próby o dużym podobieństwie umieszczone są blisko siebie na diagramie ordynacyjnym. Ocenę istotności różnic między badanymi zgrupowaniami w metodzie NMDS przeprowadzono przy użyciu nieparametrycznego testu statystycznego ANOSIM (Clarke 1993). Ocenę zależności pomiędzy występowaniem Carabidae określonych grup ekologicznych a występowaniem fitofagów nalistnych w badanych kombinacjach ochrony leszczyny przeprowadzono przy wykorzystaniu technik ordynacyjnych (ter Braak i Smilauer 1998). Zastosowano metodę PCA (Principal Components Analysis), ponieważ rozkład analizowanych danych miał charakter liniowy $(\mathrm{SD}=0,50)$. Analiza ta dokonuje uporządkowania prób wzdłuż gradientu reprezentowanego przez oś diagramu ordynacyjnego w oparciu o dane dotyczące składu gatunkowego badanych zgrupowań Carabidae. Obliczenia statystyczne i ich graficzną interpretację wykonano przy użyciu programów: Statistica 8.0 i Canoco 4.51 .

\section{Wyniki i dyskusja / Results and discussion}

Podczas dwuletnich obserwacji odłowiono łącznie 2525 osobników roślinożernych owadów. Przeprowadzone badania wykazały występowanie zdobniczki leszczynowej (Myzocallis coryli Goetze) w niewielkim nasileniu w kombinacji kontrolnej (7 osobników) i z zastosowanymi probiotykami (2 osobniki), natomiast zdecydowanie wyższą liczebność tego monofaga odnotowano w kombinacji z zastosowanym Polyversum WP (60 osobników). Liczniejszy pojaw M. coryli stwierdzono w drugim roku badań. Podobnie, jak w pierwszym roku badań szkodnik ten najliczniej wystąpił na drzewach, na których zastosowano dodatkową ochronę Polyversum WP (693 osobniki). Najmniejszą liczebność 
Tabela 1. Gatunki fitofagiczne zasiedlające liście leszczyny w badanych kombinacjach Table 1. Phytophagous species dwelling on hazel leaves in the analysed combinations

\begin{tabular}{|c|c|c|c|c|c|c|c|c|c|c|c|c|c|}
\hline \multirow{3}{*}{$\begin{array}{l}\text { Rząd } \\
\text { Rodzina } \\
\text { Order } \\
\text { Family }\end{array}$} & \multirow{3}{*}{$\begin{array}{l}\text { Gatunek dominujący } \\
\text { Jednostka taksonomiczna } \\
\text { Dominant species } \\
\text { Taxonomic unit }\end{array}$} & \multicolumn{4}{|c|}{$\begin{array}{c}\text { Kontrola } \\
\text { Control }\end{array}$} & \multicolumn{4}{|c|}{$\begin{array}{l}\text { Probiotyki (EM) } \\
\text { Probiotics (EM) }\end{array}$} & \multicolumn{4}{|c|}{ Polyversum WP } \\
\hline & & \multicolumn{2}{|c|}{2014} & \multicolumn{2}{|c|}{2015} & \multicolumn{2}{|c|}{2014} & \multicolumn{2}{|c|}{2015} & \multicolumn{2}{|c|}{2014} & \multicolumn{2}{|c|}{2015} \\
\hline & & $\mathrm{n}^{*}$ & {$[\%]$} & & {$[\%]$} & $\mathrm{n}$ & {$[\%]$} & $\mathrm{n}$ & {$[\%]$} & $\mathrm{n}$ & {$[\%]$} & $\mathrm{n}$ & {$[\%]$} \\
\hline \multicolumn{14}{|l|}{ Diptera } \\
\hline & Cecidomyiidae & 7 & 11,9 & 26 & 4,3 & 9 & 4,6 & 2 & 0,7 & 112 & 19,0 & 21 & 2,6 \\
\hline & Bibio hortulanus L., Bibionidae & - & - & 8 & 1,3 & - & - & 1 & 0,4 & - & - & - & - \\
\hline & Tipulidae & - & - & - & - & 2 & 1,0 & - & - & - & - & - & - \\
\hline & Fannia canicularis L., Muscidae & 21 & 35,6 & 43 & 7,2 & 12 & 6,1 & 17 & 6,3 & 124 & 21,1 & 31 & 3,8 \\
\hline & Thaumatomyia sp., Chloropidae & - & - & - & - & - & - & 22 & 8,2 & 7 & 1,2 & 43 & 5,3 \\
\hline & Stratiomyidae & - & - & - & - & - & - & - & - & 1 & 0,2 & - & - \\
\hline & Trypetidae & - & - & - & - & - & - & - & - & 11 & 1,9 & - & - \\
\hline & Drosophilidae & - & - & 1 & 0,2 & 2 & 1,0 & 2 & 0,7 & 6 & 1,0 & 1 & 0,1 \\
\hline & Sepsidae & - & - & 1 & 0,2 & - & - & 2 & 0,7 & - & - & - & - \\
\hline & Phoridae & - & - & 3 & 0,5 & 9 & 4,6 & - & - & 17 & 2,9 & - & - \\
\hline \multicolumn{14}{|l|}{ Homoptera } \\
\hline \multirow[t]{3}{*}{ Aphidoidea } & Myzocallis coryli Goetze. & 7 & 11,9 & 503 & 83,7 & 2 & 1,0 & 219 & 81,4 & 60 & 10,2 & 693 & 85,5 \\
\hline & Aphis fabae Scop. & 1 & 1,7 & - & - & 2 & 1,0 & - & - & - & - & - & - \\
\hline & Corylobium avellanae Schrank & - & - & 1 & 0,2 & - & - & - & - & 1 & 0,2 & 2 & 0,2 \\
\hline Cicadoidea & Cicadellidae & 7 & 11,9 & - & - & 122 & 62,2 & - & - & 218 & 37,0 & - & - \\
\hline \multicolumn{14}{|l|}{ Coleoptera } \\
\hline Curculionidae & Sitona lineatus L. & 11 & 18,6 & - & - & 10 & 5,1 & - & - & 25 & 4,2 & 1 & 0,1 \\
\hline Chrysomelidae & Phyllotreta nemorum L. & - & - & 13 & 2,2 & 1 & 0,5 & 2 & 0,7 & - & - & 10 & 1,2 \\
\hline \multirow[t]{2}{*}{ Scarabaeidae } & Melolontha melolontha $\mathrm{L}$. & 1 & 1,7 & - & - & - & - & - & - & - & - & - & - \\
\hline & Phyllopertha horticola L. & 2 & 3,4 & - & - & 1 & 0,5 & - & - & 1 & 0,2 & 1 & 0,1 \\
\hline Nitidulidae & Meligethes aeneus Fab. & - & - & - & - & 9 & 4,6 & 1 & 0,4 & - & - & - & - \\
\hline Elateridae & & - & - & - & - & 1 & 0,5 & - & - & - & - & - & - \\
\hline Thysanoptera & & - & - & - & - & 6 & 3,1 & 1 & 0,4 & 1 & 0,2 & 5 & 0,6 \\
\hline Collembola & & - & - & - & - & 6 & 3,1 & - & - & - & - & - & - \\
\hline \multicolumn{14}{|l|}{ Heteroptera } \\
\hline Pentatomidae & & - & - & - & - & - & - & - & - & 2 & 0,3 & - & - \\
\hline Miridae & Lygus sp. & 2 & 3,4 & 2 & 0,3 & 2 & 1,0 & - & - & 3 & 0,5 & 2 & 0,2 \\
\hline Coreidae & Syromastus rhombeus L. & - & - & - & - & - & - & - & - & - & - & 1 & 0,1 \\
\hline Suma - Total & & 59 & 100 & 601 & 100 & 196 & 100 & 269 & 100 & 589 & 100 & 811 & 100 \\
\hline
\end{tabular}

*n - liczba osobników - number of individuals

mszyc odnotowano w kombinacji z EM (219 osobników) i była ona o połowę niższa niż stwierdzona w kombinacji kontrolnej (503 osobników) (tab. 1).

Występowanie roślinożernych owadów zaliczane jest do jednych z najważniejszych czynników decydujących o plonowaniu upraw sadowniczych (Gantner i Jaśkiewicz 2000; Sądej i wsp. 2012). Mszyca leszczynowa, uchodząca za jednego z najgroźniejszych agrofagów występujących na krzewach Corylus L., w obu latach badań wystąpiła bardzo nielicznie i nie stanowiła realnego zagrożenia, co obserwowali również we wcześniejszych badaniach Sądej i wsp. (2010) (tab. 1).
Liczną grupę fitofagicznej entomofauny leszczyny stanowiły muchówki (Diptera). Najliczniej występowały one w obu latach obserwacji w kombinacji z zastosowanym Polyversum WP (2014 rok - 278 osobników, 2015 rok 96 osobników). Ponadto, grupę fitofagów tworzyli przedstawiciele Coleoptera z dominującym gatunkiem Sitona lineatus L., Thysanoptera, Collembola i Heteroptera (tab. 1). $\mathrm{Na}$ terenie plantacji nie odnotowano występowania najgroźniejszego szkodnika orzechów laskowych - słonkowca orzechowca (Curculio nucum L.), co świadczy o skuteczności wykonanych zabiegów chemicznych. Dodatkowo, jak 
podaje Wojciechowska (2007), odmiana Kataloński należy do jednej z najbardziej odpornych odmian leszczyny na robaczywienie orzechów przez tego szkodnika.

$\mathrm{Na}$ podstawie przeprowadzonych badań stwierdzono najliczniejsze występowanie zoofagów w kombinacji z użyciem Polyversum WP (696 osobników w 2014 roku, 328 osobników w 2015 roku). We wszystkich kombinacjach podczas dwuletnich obserwacji nasadzeń leszczyny klasę eudominantów tworzył Lasius niger L. Stosunkowo liczny zespół pożytecznych zoofagów reprezentowany był w 2015 roku przez Chrysopa carnea L., tworzącego klasę dominantów. Natomiast w pierwszym roku badań występowanie tego gatunku było uzależnione od zastosowanej ochrony. W kontroli osiągnął klasę dominanta, w strefie z EM subdominanta, a w kombinacji z Polyversum WP wyłącznie recedenta. Stosunkowo licznie występujące $\mathrm{w}$ uprawach Coccinellidae w sadzie leszczynowym wystąpiły wyłącznie w roli subrecedenta w 2014 roku, natomiast w drugim roku obserwacji rodzina ta $\mathrm{w}$ kombinacjach $\mathrm{z}$ użyciem biopreparatów osiągnęła rangę subrecedenta i recedenta. Chrząszcze te głównie reprezentowane była przez dwa gatunki Coccinella septempunctata L. i Propylea quatuordecimpunctata $\mathrm{L}$. Stosowanie probiotyków istotnie

Tabela 2. Gatunki zoofagiczne zasiedlające liście leszczyny w badanych kombinacjach

Table 2. Zoophagous species dwelling on hazel leaves in the analysed combinations

\begin{tabular}{|c|c|c|c|c|c|c|c|c|c|c|c|c|c|}
\hline \multirow{3}{*}{$\begin{array}{l}\text { Rząd } \\
\text { Rodzina } \\
\text { Order } \\
\text { Family }\end{array}$} & \multirow{3}{*}{$\begin{array}{l}\text { Gatunek dominujący } \\
\text { Jednostka taksonomiczna } \\
\text { Dominant species } \\
\text { Taxonomic unit }\end{array}$} & \multicolumn{4}{|c|}{$\begin{array}{c}\text { Kontrola } \\
\text { Control }\end{array}$} & \multicolumn{4}{|c|}{$\begin{array}{l}\text { Probiotyki (EM) } \\
\text { Probiotics (EM) }\end{array}$} & \multicolumn{4}{|c|}{ Polyversum WP } \\
\hline & & \multicolumn{2}{|c|}{2014} & \multicolumn{2}{|c|}{2015} & \multicolumn{2}{|c|}{2014} & \multicolumn{2}{|c|}{2015} & \multicolumn{2}{|c|}{2014} & \multicolumn{2}{|c|}{2015} \\
\hline & & & {$[\%]$} & & {$[\%]$} & & {$[\%]$} & $\mathrm{n}$ & {$[\%]$} & $\mathrm{n}$ & {$[\%]$} & $\mathrm{n}$ & {$[\%]$} \\
\hline \multicolumn{14}{|l|}{ Neuroptera } \\
\hline Chrysopidae & Chrysopa carnea L. & 21 & 9,6 & 19 & 9,2 & 24 & 4,7 & 17 & 8,1 & 14 & 2 & 18 & 5,5 \\
\hline Hemerobiidae & Hemerobius sp. & 4 & 1,8 & 4 & 1,9 & 1 & 0,2 & 2 & 1 & - & - & - & - \\
\hline \multicolumn{14}{|l|}{ Hymenoptera } \\
\hline Formicidae & Lasius niger $\mathrm{L}$. & 125 & 57,1 & 88 & 42,5 & 316 & 62 & 98 & 46,7 & 450 & 64,7 & 184 & 56,1 \\
\hline Braconidae & & - & - & 1 & 0,5 & - & - & - & - & - & - & - & - \\
\hline Chalcidoidea & Pteromalus Sved. & 12 & 5,5 & 15 & 7,2 & 60 & 11,8 & 16 & 7,6 & 37 & 5,3 & 22 & 6,7 \\
\hline Proctotrupidae & & - & - & 21 & 10,1 & 3 & 0,6 & 26 & 12,4 & 2 & 0,3 & 23 & 7 \\
\hline Sphecidae & & - & - & - & - & - & - & - & - & - & - & 1 & 0,3 \\
\hline Ichneumonidae & & - & - & 1 & 0,5 & - & - & - & - & 3 & 0,4 & - & - \\
\hline \multicolumn{14}{|l|}{ Coleoptera } \\
\hline Cantharidae & Cantharis fusca $\mathrm{L}$. & - & - & 1 & 0,5 & - & - & 5 & 2,4 & - & - & - & - \\
\hline \multirow[t]{7}{*}{ Coccinellidae } & Coccinella septempunctata $\mathrm{L}$. & 1 & 0,5 & - & - & - & - & 8 & 3,8 & 1 & 0,1 & 8 & 2,4 \\
\hline & Coccinella quinquepunctata $\mathrm{L}$. & 1 & 0,5 & - & - & - & - & 3 & 1,4 & 2 & 0,3 & - & - \\
\hline & Propylea quatuordecimpunctata $\mathrm{L}$. & 1 & 0,5 & 1 & 0,5 & 5 & 1 & 5 & 2,4 & 4 & 0,6 & 5 & 1,5 \\
\hline & Harmonia axyridis $\mathrm{P}$. & - & - & - & - & - & - & - & - & 1 & 0,1 & - & - \\
\hline & Adalia bipunctata $\mathrm{L}$. & 1 & 0,5 & 1 & 0,5 & - & - & - & - & 1 & 0,1 & - & - \\
\hline & Anatis ocellata $\mathrm{L}$. & - & - & - & - & - & - & - & - & 1 & 0,1 & - & - \\
\hline & Coccinula quatuordecimpustulata L. & - & - & - & - & - & - & 1 & 0,5 & - & - & - & - \\
\hline Staphylinidae & & 15 & 6,8 & - & - & 44 & 8,6 & - & - & 83 & 11,9 & - & - \\
\hline \multicolumn{14}{|l|}{ Diptera } \\
\hline Dolichopodidae & Dolichopus ungulatus L. & - & - & 7 & 3,4 & - & - & 14 & 6,7 & 21 & 3 & 1 & 0,3 \\
\hline Empididae & & 1 & 0,5 & 10 & 4,8 & - & - & - & - & - & - & 17 & 5,2 \\
\hline \multicolumn{14}{|l|}{ Dermaptera } \\
\hline Forficulidae & Forficula auricularia L. & 9 & 4,1 & 1 & 0,5 & 27 & 5,3 & - & - & 30 & 4,3 & - & - \\
\hline \multicolumn{14}{|l|}{ Heteroptera } \\
\hline Anthocoridae & Anthocoris nemorum L. & 5 & 2,3 & 12 & 5,8 & 12 & 2,4 & 7 & 3,3 & 10 & 1,4 & 23 & 7 \\
\hline Araneae & & 23 & 10,5 & 25 & 12,1 & 17 & 3,3 & 8 & 3,8 & 31 & 4,5 & 26 & 7,9 \\
\hline Lithobiomorpha & & - & - & - & - & 1 & 0,2 & - & - & 5 & 0,7 & - & - \\
\hline
\end{tabular}

*n- liczba osobników - number of individuals 
ograniczyło liczebność pożytecznej fauny z rzędu Araneae (17 osobników w 2014 roku i 8 osobników w 2015 roku), zarówno w stosunku do kontroli (23 osobników w 2014 roku, 25 osobników w 2015 roku), jak i ochrony z użyciem Polyversum WP (31 osobników w 2014 roku i 26 osobników w 2015 roku) (tab. 2).

Według Wojciechowicz-Żytko (2004) występowanie afidofauny leszczyny, jak i pozostałych najgroźniejszych szkodników, skutecznie regulowane jest przez ich naturalnych drapieżców, w szczególności: Coccinellidae, Miridae, Aphidiidae i Arachnida. W myśl podstawowych założeń integrowanej ochrony roślin, wspieranie ich występowania może ograniczyć do niezbędnego minimum użycie w sadach syntetycznych środków ochrony roślin przy jednoczesnym uzyskaniu wysokojakościowych zbiorów.

Efektywnymi bioindykatorami zmian zachodzących w uprawach roślin są chrząszcze z rodziny biegaczowatych (Kotze i wsp. 2011; Nietupski i wsp. 2015; Kosewska i wsp. 2016). W 2014 roku odłowiono łącznie 1980 osobników Carabidae, należących do 44 gatunków. Liczebność biegaczowatych stwierdzona w poszczególnych kombinacjach różniła się istotnie $(\mathrm{F}=13,25 ; \mathrm{p}=0,001)$ (tab. 3). Najwyższą średnią liczebność osobników biegaczowatych stwierdzono w kombinacji z zastosowanym preparatem Polyversum WP - 12,15 osobników/pułapkę, najmniejszą zaś w kombinacji z dodatkowo stosowanymi probiotykami (9,95 osobników/pułapkę). Istotne różnice zanotowano również w liczbie odłowionych gatunków $(F=9,46 ; p=0,008)$. Największą ich średnią liczebność stwierdzono w kombinacji z zastosowanym Polyversum WP (średnio 4,78 osobnika/pułapkę) i probiotykami (średnio 4,00 osobniki/pułapkę). Istotnie mniej gatunków Carabidae odłowiono w kombinacji kontrolnej - 3,67 osob- nika/pułapkę). Grupa gatunków dominujących Carabidae w badanych kombinacjach była podobna i tworzyły ją: Calathus fuscipes, Amara aenea i Harpalus affinis (tab. 4). Liczba gatunków oraz proporcje poszczególnych klas w układzie dominacji wskazują, że zgrupowania biegaczowatych w kombinacji z zastosowanym dodatkowo preparatem Polyversum WP cechuje duża stabilność ekologiczna (Trojan 1998). Potwierdzeniem tego są również wyliczone wartości wskaźnika różnorodności Shannona-Wienera $\left(\mathrm{H}^{\prime}=2,27\right)$ i równomierności Pielou (J' $=0,76)$ osiągające w tej kombinacji najwyższe nominały (tab. 4). Uzyskane wartości badanych wskaźników różnorodności kształtowały się na wysokim poziomie $\mathrm{w}$ porównaniu $\mathrm{z}$ badaniami prowadzonymi w sadzie jabłoniowym (Nietupski 2012). Były jednak niższe niż w naturalnych, śródpolnych zadrzewieniach (Kosewska i wsp. 2006).

Analiza NMDS wykazała, że zgrupowania Carabidae zasiedlające badane kombinacje różniły się między sobą (ANOSIM; R = 0,17; $\mathrm{p}<0,05$ ). Zgrupowania Carabidae kombinacji z zastosowanymi dodatkowo probiotykami były oddalone na wykresie ordynacyjnym NMDS od zgrupowań z kombinacji kontrolnej i Polyversum WP, a więc różniły się od nich istotnie (rys. 2).

W celu stwierdzenia zależności między występowaniem naziemnych Carabidae i fitofagami zasiedlającymi liście leszczyny w badanych kombinacjach przeprowadzono analizę kanoniczną PCA (rys. 3). Analiza diagramu ordynacyjnego wskazuje, że liście leszczyny w kombinacji z zastosowanym Polyversum WP były chętnie zasiedlane przez fitofagi. Oba gradienty opisujące te grupy były silnie skorelowane z I-szą osią ordynacyjną wykresu opisującą 96,2\% wariancji. Z osią tą skorelowane było również

Tabela 3. Wyniki testu GLM (uogólnionego modelu liniowego) dla liczebności i bogactwa gatunkowego Carabidae odłowionych w badanych kombinacjach leszczyny

Table 3. Results of GLM (General Linear Model) test of significance for abundance and richness of carabids caught in the tested combinations of hazel

\begin{tabular}{rcc}
\hline Efekt - Effect & Statystyki Walda - Wald statistics & $p$ \\
& Liczba osobników - Number of individuals & \\
Kombinacje - Combinations & 13,25 & 0,001 \\
\hline
\end{tabular}

Średnia liczebność - Mean number

Kontrola - Control

10,90

Polyversum WP

12,15

Probiotyki (EM) - Probiotics (EM)

9,95

Bogactwo gatunkowe - Abundance

Kombinacje - Combinations

9,46

0,008

Średnia liczebność - Mean number

Kontrola - Control

3,66

Polyversum WP

4,78

Probiotyki (EM) - Probiotics (EM)

4,00 


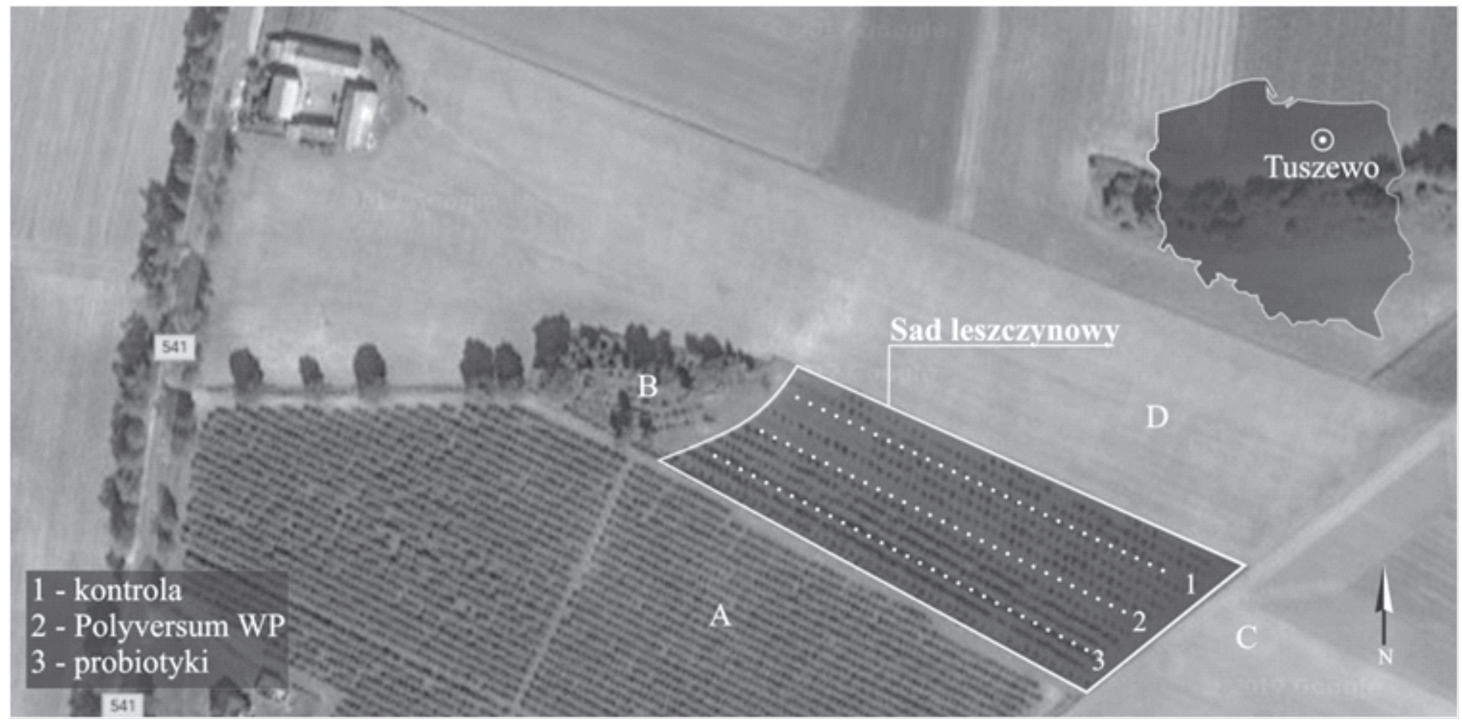

Rys. 1. Schemat rozmieszczenia powierzchni badawczych $(1,2,3)$ oraz upraw sąsiadujących: sad wiśniowy (A), zadrzewienie śródpolne (B), grunty rolne (C, D)

Fig. 1. The layout of the distribution of research areas $(1,2,3)$ and adjacent plantations: cherry orchard (A), mid-field trees (B), arable land $(\mathrm{C}, \mathrm{D})$

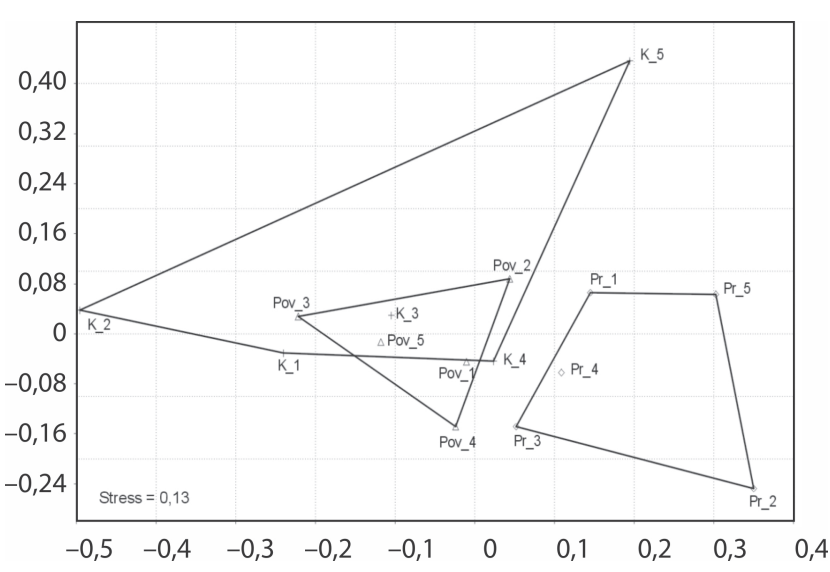

Rys. 2. Diagram niemetrycznego skalowania wielowymiarowego (NMDS) przeprowadzonego w oparciu o miarę podobieństwa Morisita dla naziemnych zgrupowań Carabidae badanych kombinacji leszczyny (K - kontrola; Pov - Polyversum WP; Pr-probiotyki)

Fig. 2. Diagram of the non-symmetrical multi-dimensional scaling (NMDS) based on the Morisits overlap index and conducted for terrestrial communities of Carabidae in the analysed hazel combinations ( $\mathrm{K}$ - control; Pov - Polyversum WP; $\mathrm{Pr}$ - probiotics)

występowanie większości wyróżnionych grup ekologicznych Carabidae, m.in. drapieżnych gatunków z grup małych i dużych zoofagów. W kombinacji kontrolnej obserwowano natomiast liczniejsze występowanie Carabidae z grupy średnich zoofagów o jesiennym rytmie rozwojowym. Diagram ordynacyjny nie ujawnił natomiast żadnych korelacji między występowaniem badanych grup Carabidae oraz występowaniem nalistnych fitofagów, a dodatkowym stosowaniem probiotyków.

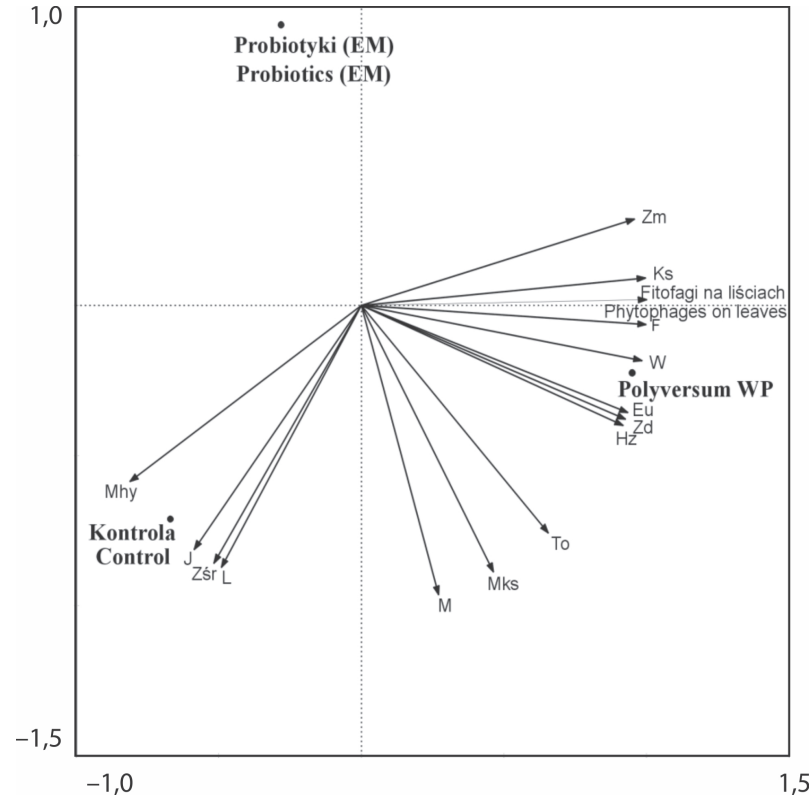

Rys. 3. Diagram analizy kanonicznej (PCA) prezentujący zależność między grupami ekologicznymi Carabidae odłowionymi w badanych kombinacjach a liczebnością fitofagów na liściach leszczyny ( $\mathrm{J}$ - gatunki jesienne; $\mathrm{W}$ - gatunki wiosenne; Zd - zoofagi duże; Zśr - zoofagi średnie; Zm - zoofogi małe; Hm-hemizoofagi; Ks-kserofile; Mks - mezokserofile; M - mezofile; Mhy - mezohygrofile; To - gatunki terenów otwartych; Eu - gatunki eurytopowe, $\mathrm{L}$ - gatunki leśne)

Fig. 3. Prinicpal Component Analysis (PCA) diagram presenting relationships between ecological groups of Carabidae captured in the analysed combinations versus the abundance of phytophagous organisms on hazel leaves ( $\mathrm{J}$ - autumn species; W - spring species; Zd - large zoophages; Zśr - medium zoophages; Zm - small zoophages; Hm - hemizoophages; Ks - xerophiles; Mks - mesoxerophiles; M - mesophiles; Mhy - mesohygrophiles; To - open land species; Eu - eurytopic species, $\mathrm{L}$ - forest species) 
Tabela 4. Skład gatunkowy i dominacja naziemnych Carabidae odłowionych na badanych kombinacjach w uprawie leszczyny Table 4. Species composition and dominance of terrestrial Carabidae captured on the analysed sites in a hazel plantation

\begin{tabular}{|c|c|c|c|c|c|c|}
\hline \multirow{3}{*}{$\begin{array}{l}\text { Gatunek } \\
\text { Species }\end{array}$} & \multicolumn{6}{|c|}{ Badana kombinacja - Study combination } \\
\hline & \multicolumn{2}{|c|}{$\begin{array}{c}\text { kontrola } \\
\text { control }\end{array}$} & \multicolumn{2}{|c|}{ Polyversum WP } & \multicolumn{2}{|c|}{$\begin{array}{c}\text { probiotyki } \\
\text { probiotics (EM) }\end{array}$} \\
\hline & $\mathrm{n}^{*}$ & {$[\%]$} & $\mathrm{n}$ & {$[\%]$} & $\mathrm{n}$ & {$[\%]$} \\
\hline 1 & 2 & 3 & 4 & 5 & 6 & 7 \\
\hline Amara aenea (De Geer, 1774) & 95 & 14,5 & 134 & 18,4 & 100 & 16,8 \\
\hline Amara bifrons (Gyllenhal, 1810) & 11 & 1,7 & 7 & 1,0 & 20 & 3,4 \\
\hline Amara communis (Panzer, 1797) & 0 & 0,0 & 0 & 0,0 & 1 & 0,2 \\
\hline Amara consularis (Duftschmid, 1812) & 1 & 0,2 & 1 & 0,1 & 1 & 0,2 \\
\hline Amara convexior Stephens, 1828 & 0 & 0,0 & 1 & 0,1 & 0 & 0,0 \\
\hline Amara familiaris (Duftschmid, 1812) & 3 & 0,5 & 1 & 0,1 & 1 & 0,2 \\
\hline Amara plebeja (Gyllenhal, 1810) & 0 & 0,0 & 0 & 0,0 & 2 & 0,3 \\
\hline Amara spreta Dejean, 1831 & 0 & 0,0 & 2 & 0,3 & 0 & 0,0 \\
\hline Anchomenus dorsalis (Pontoppidan, 1763) & 6 & 0,9 & 2 & 0,3 & 1 & 0,2 \\
\hline Badister bullatus (Schrank, 1798) & 0 & 0,0 & 1 & 0,1 & 0 & 0,0 \\
\hline Broscus cephalotes (Linnaeus, 1758) & 1 & 0,2 & 1 & 0,1 & 2 & 0,3 \\
\hline Calathus ambiguus (Paykull, 1790) & 18 & 2,8 & 13 & 1,8 & 12 & 2,0 \\
\hline Calathus cinctus Motschulsky, 1850 & 8 & 1,2 & 2 & 0,3 & 7 & 1,2 \\
\hline Calathus erratus (Sahlberg, 1827) & 34 & 5,2 & 21 & 2,9 & 19 & 3,2 \\
\hline Calathus fuscipes Goeze, 1777 & 279 & 42,7 & 206 & 28,3 & 234 & 39,2 \\
\hline Calathus melanocephalus (Linnaeus, 1758) & 6 & 0,9 & 28 & 3,8 & 15 & 2,5 \\
\hline Carabus auratus Linnaeus, 1761 & 0 & 0,0 & 1 & 0,1 & 1 & 0,2 \\
\hline Clivina fossor (Linnaeus, 1758) & 2 & 0,3 & 6 & 0,8 & 1 & 0,2 \\
\hline Cymindis angularis (Gyllenhal, 1810) & 1 & 0,2 & 0 & 0,0 & 0 & 0,0 \\
\hline Dolichus halensis (Schaller, 1783) & 0 & 0,0 & 1 & 0,1 & 0 & 0,0 \\
\hline Dyschirius globosus (Herbst, 1784) & 1 & 0,2 & 0 & 0,0 & 0 & 0,0 \\
\hline Harpalus affinis (Schrank, 1781) & 58 & 8,9 & 104 & 14,3 & 57 & 9,5 \\
\hline Harpalus anxius (Duftschmid, 1812) & 1 & 0,2 & 0 & 0,0 & 3 & 0,5 \\
\hline Harpalus griseus (Duftschmid, 1812) & 1 & 0,2 & 2 & 0,3 & 3 & 0,5 \\
\hline Harpalus latus (Linnaeus, 1758) & 1 & 0,2 & 1 & 0,1 & 0 & 0,0 \\
\hline Harpalus luteicornis (Duftschmid, 1812) & 0 & 0,0 & 2 & 0,3 & 0 & 0,0 \\
\hline Harpalus pumilus Sturm, 1818 & 10 & 1,5 & 21 & 2,9 & 15 & 2,5 \\
\hline Harpalus rubripes (Duftschmid, 1812) & 0 & 0,0 & 2 & 0,3 & 1 & 0,2 \\
\hline Harpalus rufipes (De Geer, 1774) & 24 & 3,7 & 23 & 3,2 & 16 & 2,7 \\
\hline Harpalus smaragdinus (Duftschmid, 1812) & 9 & 1,4 & 10 & 1,4 & 4 & 0,7 \\
\hline Harpalus tardus (Panzer, 1797) & 41 & 6,3 & 26 & 3,6 & 28 & 4,7 \\
\hline Metallina lampros (Herbst, 1784) & 3 & 0,5 & 14 & 1,9 & 8 & 1,3 \\
\hline Metallina properans (Stephens, 1828) & 0 & 0,0 & 2 & 0,3 & 2 & 0,3 \\
\hline Nebria brevicollis (Fabricius, 1792) & 3 & 0,5 & 7 & 1,0 & 4 & 0,7 \\
\hline Notiophilus palustris (Duftschmid, 1812) & 0 & 0,0 & 1 & 0,1 & 0 & 0,0 \\
\hline Poecilus cupreus (Linnaeus, 1758) & 0 & 0,0 & 0 & 0,0 & 1 & 0,2 \\
\hline Poecilus lepidus (Leske, 1785) & 3 & 0,5 & 30 & 4,1 & 17 & 2,8 \\
\hline Poecilus versicolor (Sturm, 1824) & 4 & 0,6 & 11 & 1,5 & 1 & 0,2 \\
\hline Pterostichus melanarius (Illiger, 1798) & 24 & 3,7 & 42 & 5,8 & 16 & 2,7 \\
\hline Pterostichus niger (Schaller, 1783) & 0 & 0,0 & 1 & 0,1 & 0 & 0,0 \\
\hline Pterostichus oblongopunctatus (Fabricius, 1787) & 1 & 0,2 & 0 & 0,0 & 0 & 0,0 \\
\hline
\end{tabular}




\begin{tabular}{|c|c|c|c|c|c|c|}
\hline 1 & 2 & 3 & 4 & 5 & 6 & 7 \\
\hline Syntomus foveatus (Fourcroy, 1785) & 3 & 0,5 & 0 & 0,0 & 4 & 0,7 \\
\hline Syntomus truncatellus (Linnaeus, 1761) & 1 & 0,2 & 0 & 0,0 & 0 & 0,0 \\
\hline Trechus quadristriatus (Schrank, 1781) & 1 & 0,2 & 2 & 0,3 & 0 & 0,0 \\
\hline Suma - Total & 654 & 100,0 & 729 & 100,0 & 597 & 100,0 \\
\hline Gatunki - Species & \multicolumn{2}{|c|}{31} & \multicolumn{2}{|c|}{35} & \multicolumn{2}{|c|}{31} \\
\hline Shannon H’ Log Base 2,718 & \multicolumn{2}{|c|}{2,01} & \multicolumn{2}{|c|}{2,27} & \multicolumn{2}{|c|}{2,13} \\
\hline Pielou J' & \multicolumn{2}{|c|}{0,72} & \multicolumn{2}{|c|}{0,76} & \multicolumn{2}{|c|}{0,73} \\
\hline
\end{tabular}

*n - liczba osobników - number of individuals

\section{Wnioski / Conclusions}

1. Głównym zagrożeniem plantacji leszczyny w latach badań były mszyce z gatunkiem dominującym - M. coryli.

2. Stosowanie dodatkowej ochrony leszczyny z użyciem preparatu Polyversum WP stymuluje liczniejsze występowanie fitofagów nalistnych oraz naziemnych ga- tunków pożytecznych Carabidae. Odwrotną zależność stwierdzono natomiast $\mathrm{w}$ kombinacji $\mathrm{z}$ dodatkowym stosowaniem probiotyków.

3. W uprawie leszczyny zalecane jest stosowanie dodatkowej ochrony probiotykami: EmFarma Plus i EmFarma 5 ze względu na mniej liczny pojaw fitofagów, w tym groźnego szkodnika tej rośliny, jakim jest M. coryli.

\section{Literatura / References}

Aleksandrowicz O.R. 2004. Biegaczowate (Carabidae). s. 28-42. W: „Fauna Polski - charakterystyka i wykaz gatunków” (W. Bogdanowicz, E. Chudzicka, I. Pilipiuk, E. Skibińska, red.). Muzeum i Instytut Zoologii Polskiej Akademii Nauk, Warszawa, 509 ss.

Ciemniewska H., Ratusz K. 2012. Charakterystyka orzechów laskowych trzech odmian leszczyny uprawianej w Polsce. [Characteristics of hazelnuts from three hazel cultivars grown in Poland]. Rośliny Oleiste - Oilseed Crops 33 (2): 273-283.

Clarke K.R. 1993. Non-parametric multivariate analyses of changes in community structure. Australian Journal of Ecology 18 (1): 117-143. DOI: 10.1111/j.1442-9993.1993.tb00438.x.

Daly M.J., Stewart D.P.C. 1999. Influence of "Effective Microorganisms" (EM) on vegetable production and carbon mineralization - A preliminary investigation. Journal of Sustainable Agriculture 14 (2/3): 15-25. DOI: 10.1300/J064v14n02 04.

Gantner M., Jaśkiewicz B. 2000. Mszyce żerujące na krzewach leszczyny uprawnej (Corylus L.). Ochrona Roślin 44 (11): 8-25.

Gantner M. 2009. Koszty ochrony plantacji leszczyny przed szkodnikami i chorobami. [Costs of hazelnut protection against pests and diseases]. Progress in Plant Protection/Postępy w Ochronie Roślin 49 (4): 1610-1616.

Gantner M. 2010. Aktualne problemy wystepujace w uprawach małoobszarowych na przykładzie leszczyny. [Current problems in minor crops on hazelnut example]. Progress in Plant Protection/Postępy w Ochronie Roślin 50 (4): 1583-1591.

Ghirardello D., Prosperini S., Zeppa G., Gerbi V. 2010. Phenolic acid profile and antioxidant capacity of hazelnut (Corylus avellana L.) kernels in different solvent systems. Journal of Food and Nutrition Research 49 (4): 195-205.

Hůrka K. 1996. Carabidae of the Czech and Slovak Republics. Kabourek, Zlin, 565 pp.

Jamiołkowska A., Hetman B. 2016. Mechanizm działania preparatów biologicznych stosowanych w ochronie roślin przed patogenami. Annales Universitatis Mariae Curie-Skłodowska, Sectio E, Agricultura 71 (1): 13-29.

Kasprzak K., Niedbała W. 1981. Wskaźniki biocenotyczne stosowane przy porządkowaniu i analizie danych w badaniach ilościowych. s. 397-416. W: „Metody stosowane w zoologii gleby” (M. Górny, L. Grüm, red.). Państwowe Wydawnictwo Naukowe, Warszawa, 483 ss.

Kosakowski K., Grzelak M., Kosakowski A. 2013. Wpływ zastosowania preparatów probiotycznych na zdrowotność, jakość oraz plon wybranych roślin. [The effect of applied probiotic preparations on health, quality and yield of selected crops]. Journal of Research and Applications in Agricultural Engineering 58 (3): 261-266.

Kosewska A., Nietupski M., Ciepielewska D. 2006. Skład i struktura zgrupowań Carabidae (Coleoptera) zasiedlających zadrzewienia śródpolne okolic Olsztyna. Wiadomości entomologiczne 25, Suplement 1: 49-59.

Kosewska A., Nietupski M., Nijak K., Skalski T. 2016. Effect of plant protection on assemblages of ground beetles (Coleoptera, Carabidae) in pea (Pisum L.) and lupine (Lupinus L.) crops. Periodicum Biologorum 118 (3): 213-222. DOI: 10.18054/pb.2016.118.3.3911.

Kosicka D., Wolna-Maruwka A., Trzeciak M. 2015. Wpływ preparatów mikrobiologicznych na glebę oraz wzrost i rozwój roślin. [The influence of microbial inoculates on morphological traits in plants]. Kosmos Problemy Nauk Biologicznych 64 (2): 327-335.

Kotze D.J., Brandmayr P., Casale A., Dauffy-Richard E., Dekoninck W., Koivula M.J., Lövei G.L., Mossakowski D., Noordijk J., Paarmann W., Pizzolotto R., Saska P., Schwerk A., Serrano J., Szyszko J., Taboada A., Turin H., Venn S., Vermeulen R., Zetto T. 2011. Forty years of carabid beetle research in Europe - from taxonomy, biology, ecology and population studies to bioindication, habitat assessment and conservation. ZooKeys 100: 55-148. DOI: 10.3897/zookeys.100.1523.

Larsson S.G. 1939. Entwicklungstypen und Entwicklungszeiten der dänischen Carabiden. Development types and development time of the Danish Carabidae. Entomologische Meddelelser 20: 270-560.

Małuszyńska E., Szydłowska A., Martyniak D., Dziamba Sz., Dziamba J. 2012. Wpływ preparatów zawierających efektywne mikroorganizmy na zdolność kiełkowania nasion z upraw ekologicznych. Biuletyn Instytutu Hodowli i Aklimatyzacji Roślin 263: 33-42.

Markuszewski B., Kopytowski J., Bieniek A., Krzymińska I. 2017. Wpływ biopreparatów na plonowanie i jakość świeżych owoców laskowych. s. 118-125. W: „Rolnictwo XXI wieku - problemy i wyzwania” (D. Łuczycka, red.). Idea Knowledge Future, Wrocław, 479 ss. 
Morelowska M., Świątek M., Sekutowski T.R. 2017. Skuteczność działania preparatu EmFarma Plus i Coniothyrium minitans w odniesieniu do patogena wywołującego zgniliznę twardzikową. s. 135-147. W: „,Rolnictwo XXI wieku - problemy i wyzwania” (D. Łuczycka, red.). Idea Knowledge Future, Wrocław, 479 ss.

Nietupski M. 2012. Naziemne biegaczowate (Coleoptera: Carabidae) występujące w sadach jabłoniowych objętych różnymi systemami produkcji. [Ground beetles (Coleoptera: Carabidae) occurring in apple orchards under different production systems]. Progress in Plant Protection/Postępy w Ochronie Roślin 52 (2): 360-365. DOI: 10.14199/ppp-2012-066.

Nietupski M., Kosewska A., Markuszewski B., Sądej W. 2015. Soil management system in hazelnut groves (Corylus sp.) versus the presence of ground beetles (Coleoptera: Carabidae). Journal of Plant Protection Research 55 (1): 26-34. DOI: 10.1515/jppr-2015-0004.

Nikolova I., Georgieva N. 2015. Systems of organic farming in spring vetch II: Biological response of Aeolothrips intermedius Bagnall and Coccinella septempunctata L. Pesticides and Phytomedicine 30 (3): 147-153. DOI: 10.2298/PIF1503147N

Paśmionka I., Kotarba K. 2015. Możliwości wykorzystania efektywnych mikroorganizmów w ochronie środowiska. [Possibile application of effective microorganisms in environmental protection]. Kosmos Problemy Nauk Biologicznych 64 (1): 173-184.

Piskornik Z., Wojciechowska M., Korfel J. 1998. Uprawa leszczyny szansą sadownictwa makroregionu środkowo-wschodniego w przededniu przyjęcia Polski do Unii Europejskiej. Zeszyty Naukowe Akademii Rolniczej w Krakowie 57 (2): $573-577$.

Sądej W., Ciepielewska D., Pomianowska E. 1997. Entomofauna wiesiołka dwuletniego (Oenothera biennis L.) i jego rola w agrocenozie. Rośliny Oleiste - Oilseed Crops 18 (2): 365-370.

Sądej W., Markuszewski B., Nietupski M. 2010. Mszyce występujące na plantacji leszczyny w Tuszewie koło Lubawy. [Aphids in a hazelnut plantation in Tuszewo near Lubawa]. Progress in Plant Protection/Postępy w Ochronie Roślin 50 (4): 1742-1746.

Sądej W., Nietupski M., Markuszewski B. 2012. Entomofauna leszczyny uprawianej w północno-wschodniej Polsce. [Entomofauna of hazelnut plantation in the north-eastern regions of Poland]. Progress in Plant Protection/Postępy w Ochronie Roślin 52 (4): $854-858$. DOI: $10.14199 / \mathrm{ppp}-2012-147$.

Stachowiak M. 2008. Przegląd systematyczny biegaczowatych Polski (Coleoptera, Carabidae) - wersja skrócona. www.entomo.p1/ coleoptera/carabidae/index.php [dostęp: 22.03.2017].

Ter Braak C.J.F., Smilauer P. 1998. CANOCO Reference Manual and User's Guide to Canoco for Windows: Software for Canonical Community Ordination (version 4). Microcomputer Power, Ithaca, USA, 352 pp.

Trojan P. 1998. Nowe perspektywy w badaniach entomofaunistycznych. s. 137-155. W: Materiały zjazdowe. Wiadomości Entomologiczne 17, Suplement 43. Zjazd Polskiego Towarzystwa Entomologicznego, Poznań, 4-6 września 1998, 207 ss.

Twardowski J. 2013. Rolnictwo ekologiczne nie sprzyja szkodnikom. Ekonatura 2: 12-13.

Wojciechowicz-Żytko E. 2004. Predators occurring in Myzocallis coryli Goetze (Homoptera, Aphidodea) colonies on hazel (Corylus L.). [Drapieżce występujące w koloniach Myzocallis coryli Goetze (Homoptera, Aphidodea) na leszczynie (Corylus L.)]. Journal of Plant Protection Research 44 (3): 181-188.

Wojciechowska M. 2007. Leszczyna. Działkowiec, 60 ss.

Wolna-Maruwka A., Schroeter-Zakrzewska A., Borowiak K. 2010. Wpływ preparatu Em na stan mikrobiologiczny podłoża przeznaczonego do uprawy pelargonii (Pelargonium $\times$ hortorum). [Effect of em inoculum on the microbiological state of substrate designed for pelargonium (Pelargonium $\times$ hortorum)]. Nauka Przyroda Technologie 4 (6): 1-12.

Zalecenia Ochrony Roślin 2016/17 [online]. www.ior.poznan.pl/baza/ [dostęp: 22.03.2017].

Zdyb H. 2010. Leszczyna. Powszechne Wydawnictwo Rolnicze i Leśne, Warszawa, 249 ss.

Zydlik P. 2008. Wykorzystanie preparatów pochodzenia naturalnego w zwalczaniu niektórych chorób roślin sadowniczych. [Application of preparations of natural origin in disease control of fruit growing plants]. Nauka Przyroda Technologie 2 (1): 1-6. 